\title{
STUDIES ON THE MAXILLARY MERVE BLOCK
}

Part 2. Clinical investigation.

By

\section{H. SAITO}

\section{From the Oto-Rhino-Laryngology Department, Tokyo Medical College (Director: Prof. T. Shiroiwa)}

Based on the fundamental and technical study reported in Part 1, the author applied the new technique of the maxillary nerve block in many maxillary operations (mainly, chronic sinusitis), and the effects of anesthesia were described.

1) The effect of the anesthesia: The analysia was obtained more easily by the new technique than the usual technique. Successful analgesia was obtained in about $95 \%$ of the cases.

2) The influence on bleeding; : Using this new method, bleeding during the operation was markedly reduced. These effects lasted for about 50 60 minutes.

3) The blood pressure, the pulse and the respiration rate decreased but they were within normal limits.

Also there were no harmful or continuous side effects in all cases.

4) Since there has been no single method to obtain complete anesthesia of maxillary nerve, several different methods have been employed at the same time. The simplicity and the certainty of the new method are emphasized.

\section{翼口蓋窩における神経伝達麻酔の臨床的研究}

\section{第 2 編 臨床的応用に関する研究}

\section{東京医科大学耳悬咽喉科教室（主任 日岩俊䧼教授） \\ 泰野赤十字病院耳，䭪呁喉科医長}

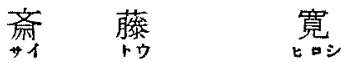

\begin{tabular}{|c|c|c|c|}
\hline & 次 & 第6章 考 & 按 \\
\hline 筑 1 章 & 緒言と研究材料 & 第 7 章 結語 & 主慗参虏 攻擜 \\
\hline \multirow[t]{3}{*}{ 第 2 嗥 } & 䣲酷效果 & & \\
\hline & 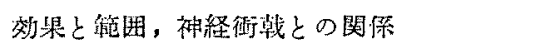 & & 第1章＼cjkstart緒 \\
\hline & 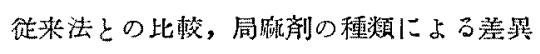 & \multirow{2}{*}{\multicolumn{2}{|c|}{$\begin{array}{l}\text { 上䫇神経の伝達麻酕 (以下伝麻々略称) 法に関する研 } \\
\text { 究は } 1900 \text { 年 Matus-Braum 氏以来, 璉々研究され今日 }\end{array}$}} \\
\hline \multirow[t]{3}{*}{ 第了祽 } & 出血に改代す影䖽 & & \\
\hline & 出血抑制效果 & \multirow{2}{*}{\multicolumn{2}{|c|}{$\begin{array}{l}\text { に至つているが，笑地䧗床上の灾用法に就いてはなお一 } \\
\text { 般の耳鼻咽涘科医が容易に確実な効果をあげ得るるのは }\end{array}$}} \\
\hline & 出血抑制 と麻醉彸果 & & \\
\hline 第 4 等 & 血圧腿膊呼吸に及ぼす影響 & \multicolumn{2}{|c|}{ 見出されていなかつた・著者は上䫈洞根治手術時に洞粘 } \\
\hline 第5 章 & 副作用について & \multirow{2}{*}{\multicolumn{2}{|c|}{$\begin{array}{l}\text { 膜麻酤の困難から患医共にとの苦痛に悦まされることの } \\
\text { あるため,色々と考按工夫して；此較的実施容易な，而 }\end{array}$}} \\
\hline & 括 & & \\
\hline
\end{tabular}


も有効率の高い，新方法を按出，その力法の詳細を第 1 編に和いて述べた・本編に招いてては新方法による実地施 行上の効果の呏際を検当すると共に，上顎骨手術時に上 顎神経を遮断した場合，臨床上考慮す可き諸点，即ち血 王の変動, 出血に及ば寸影響，あるいは種ななる副作用 の発現等について検討して見た，殊にその副作用に就て

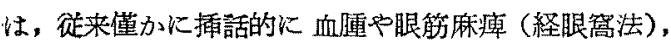
視神経麻痺（経眼简法一Halle の例）等を来したことが 知られている程度に過ぎないので，これ等の諸点につい ても再検討を加えこコ報告する次第である。

研究材料としては, 泰野赤十字病院耳鼻咽喉科沶活 る上顎洞根治手術 28 側，上顎洞経由穊骨洞開放術 139 侧，上顎骨部分万至全摘出患者 6 側計 173 側，98 人（～ 61，古37人）に就て研究した。患者の年命法11才〜74

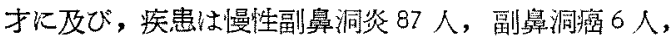
荬根裂胞 2 人, 球後視束炎 1 人, 術後性煩部䍂胞 1 人, 上頻洞血瘤腫 1 人でする。上顎神経伝麻は著者の方法に 従つて施行し 全症例について詳細に実態を観察して見 た。

注射針は径 $1 \mathrm{~mm}$, 長さ $70 \mathrm{~mm}$, 切口 $45^{\circ}$ を有しピ= 一ル鞘にて 4, 4.5, $5 \mathrm{~cm}$ 個所火目盛を置いた強鞄なる伝 麻針 (short-bevel nerve blocking needle) t使用し た。

\section{第 2 章 麻 酥効果}

著者法に従つて施行した翼口蓋简内伝洼休酸法に上つ て得られた麻醉効果について述べる。

症例; 慢性副鼻 洞炎 152 側, 副且洞癌 6 侧, 計 158 側，年令 13 才万至 74 才 (満年令)に互る男女である。

症例の大多数（即ち癌患者を除いて）に就てできるだ 时－効果判定を正磪にするため，本伝達麻酔法以外の操 作としては凡て一律に（1）基碟的酪晏麻酔は施行せず (2) 固有鼻腔任半数例怯 $4 \%$ Xylocairn + Adrenali.2 液 Gaze タンポン施行，半数例は清净化のみで無処置 (3) 上顎骨顔面壁の粘骨粘下（切開部）に $1 \%$ Novocain 又 は $1 \%$ Xylocain 溶液を $10 \mathrm{cc}$ ( $+3 \mathrm{cc}$ 以内) 局所に 浸 潤注射 (4) 止血戍としては一律に Jrombogen 注射液 $5 \mathrm{cc}$ を皮下注射し，条件の均一を計つた。

判定の基準

$(H)=$ 上頭神経の全支配領域に互つて，又は洞外に互 つて麻醉効果登発揮せ万症例.

$(H)=$ 洞内完全無痛（極く一部の節骨神経支配域を除 いて）を獲得せる症例.

$(十)=$ 洞内一部に疼痛を訴觉たるも施術上支障のなか
つた症例.

$(一)=$ 殆んど伝麻効果乏しきもの及び応答明暸ならず して効果の判定不正確だつた症例.

第 1 裴 雨 醉 效 臬

\begin{tabular}{|c|c|c|c|c|}
\hline 效果 & 観察例数 & 荄当例数 & 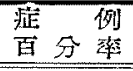 & 信 賴 限 界 \\
\hline (H) & 158 & 21 & $13.29 \%$ & $18.46 \sim 9.55 \%$ \\
\hline$(H)$ & 158 & 86 & $54.43 \%$ & $60.77 \sim 47.83 \%$ \\
\hline$(+)$ & 158 & 44 & $27.85 \%$ & $34.06 \sim 22.47 \%$ \\
\hline$(-)$ & 158 & 7 & $4.43 \%$ & $8.12 \sim 2.53 \%$ \\
\hline
\end{tabular}

麻酔䉐围：最も多いのは洞内無痛化を得るものであ る. (十) 效果例の有痛部俚多くは洞内菌槽突起部, 沪

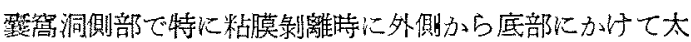
い索状物(神経分枝と思われる)を明視した症例にみられ る、程展は一過性，軽度で小範囲の疼痛で他の手段を全 く要しないものと，一局部ながら疼痛や入強く、該部に

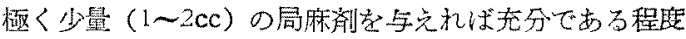
のものとである（第1，2 図）.

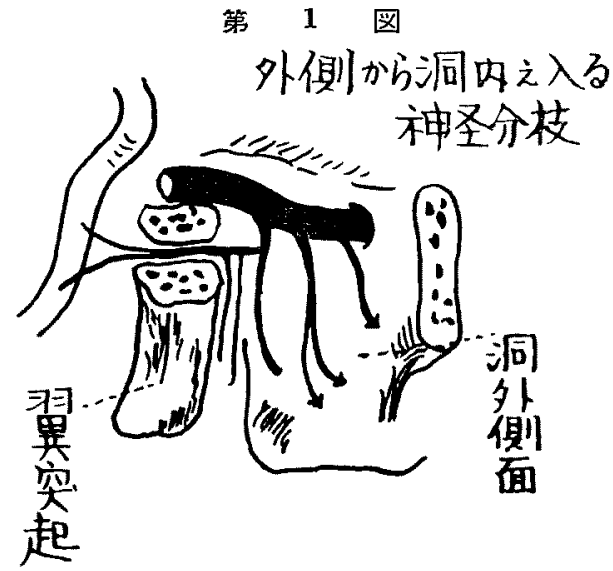

（H）効果症例では洞内は無痛化する。但し一概に洞

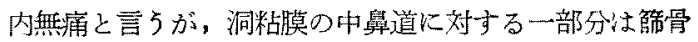
神経の支配領域であるから，該部に島状有痛部は往々に して存在するがこれは麻酔の不完全によるものではな

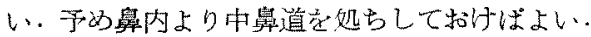

これ等 $(H)$ 中 $(+)$ の效果例に欢られる軽, 小範围有 痛現象は，实地臨床に打いてては基礎酪妄麻酔の実施や，

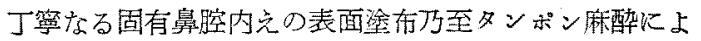
つて容易に完全無痛手術とすることができる。

効果（一）の例中には全々失敗した症例の他, 多少有 効とは思わるつがそれのみで怯可なりの苦痛を訴之，無 
第 2 図 洞内人現付内神圣分枝

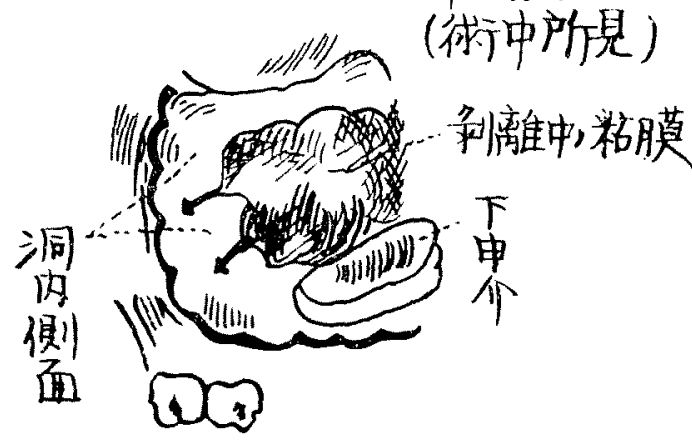

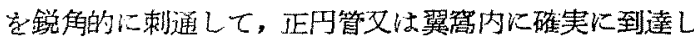
て始めて有効に作用するのであるが，これは简及びその 附近を埋めている組織が相当に強鞄で，従来の方法で刺 入した埸合目的の部位に到達しない途中で注射したので

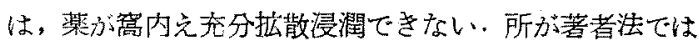
針先が終始骨面をはつて简の近くに到咭さ光していれば

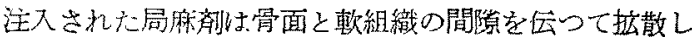

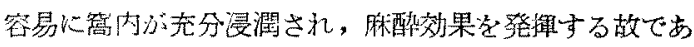
る・この事実は本法を屍体に施行し刺入経路の骨に対す る沿壁性及び色素削走便用してその拨散性を観察する事

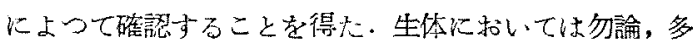

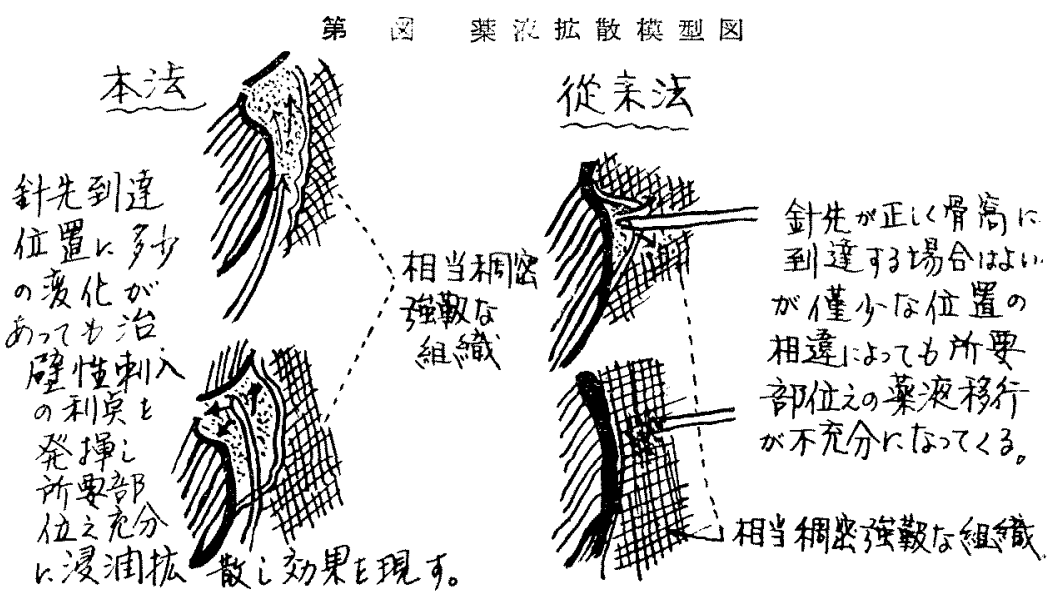

痛手術とは言い得ない症例 る含えている。この無效例は 解剖学的異常, ことにSpina pterggoidea anterior $か 3$ 注

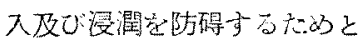
考克られる. Spina pterygoidea anterior $の$ 出現率は 低く 野村域 4 6.5\%\%，著者 $4.5 \sim 6.096$ (約) 一, 無効例刀 4.43\% と近似定示吉こそはこ

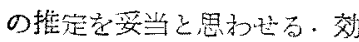
果 $(-)$ 例の性别快男性 4 側, 女性了側であつ方。

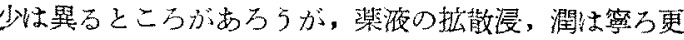

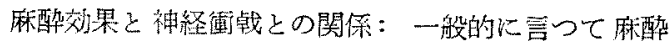
效果は若し 神経幹刺入が最有效と考皇るならば，勿論 その效果俚神経衝㦸の程度に比例与可さである。しかし ながら害地臨㕅上必要で充分な积酔効果を举け゚ることを

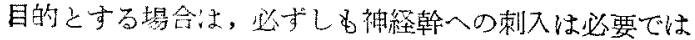

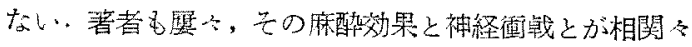

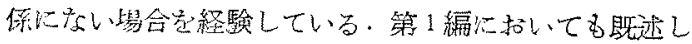
たょうに浴壁性刺入に際して多くの应例で針失は先つ翼

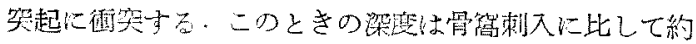

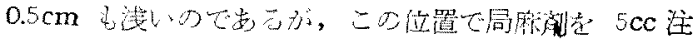

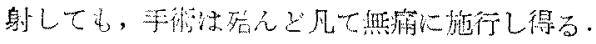

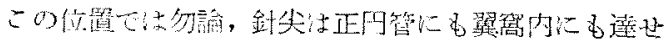

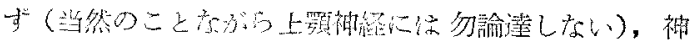

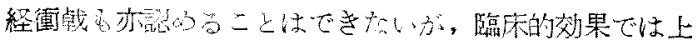

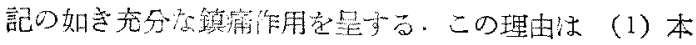

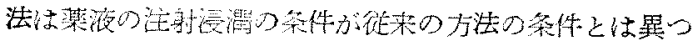

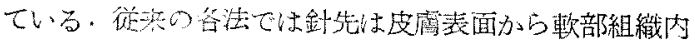

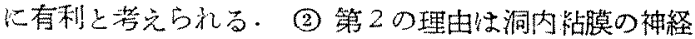

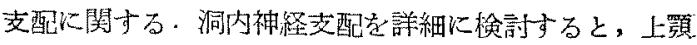

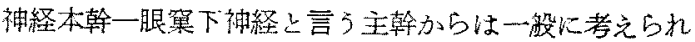
ているほと゚広範专な支配严けていない（多数の眼剖学

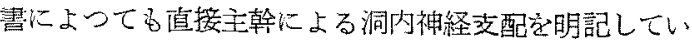
るものは㱠んどない）上り広く号い:支配は翼口蓋简及

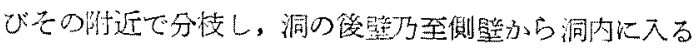
知覚校によつて行なかれていると考党られる。試及に主

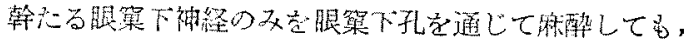

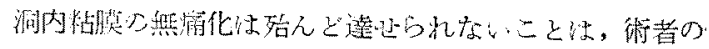

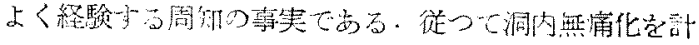

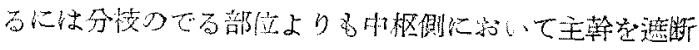

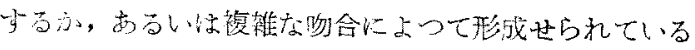

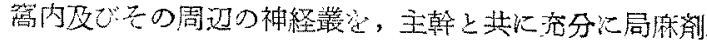

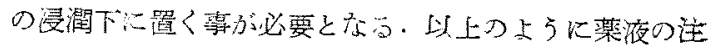
射，浸潤には遮断すべ神経の部位が主要な条件となる 
のであつて，神経幹に命中すると起る鿉㦸の程度は必ず しも麻酔效果とは平行しないるのである.即ら，同じく神 経㣫㦸の出現をみてもそれが部位的に分枝，中枢側桲入 のためか，末梢側刺入のためかは不明の篔である・且つ

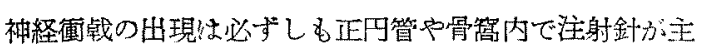
幹纪命中した時だけのるのではなく，野村氏る神経筫者

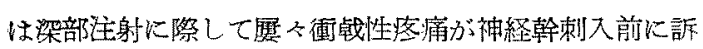
えられると述へているることに本法に执、ては、上枵骨外 側壁に沿5て針先が進められるために，その部を走行す

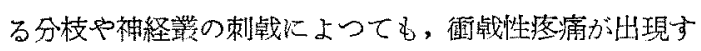
る可能性は出る。これを要するに理論的にも神経幹内一 の刺入と麻酔の程度との間に果してどの程度相関々保が あるかは，著者はな和研究途上にあるが，実地臨床上の

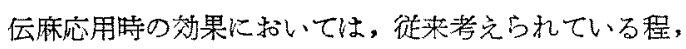
神経衝戟上麻酔効果々は不可分なるのではない。

遅延反灾及び麻酔の持続に就いて：元来，伝麻には 遅延反応 (delayed Reaktion) があつて, 遮断した部 位から特間の経過と共に未梢部に効果が及ら゙ものです

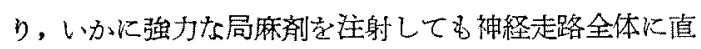
らに痛覚が組織内から消失する事はない,(Pitkin). 本 法にむいてもこの現象を認め, 麻酔効果の低い液程その 効果出現時間住渥く（時に1乃至2 分，時にそれ以上を 要する)，亦闻人的差異も認るられるよ5である，局麻 凨の種類によつても異り，Procain は Xylccain に比 し効果の出現が遅い，麻酔の持続時間は䔉削の種類や附 加郕の有無, 多寡 (Adrenalin, Hyaluronidase 等) に より、岁るいは各種の Premedication によつてもそれ ぞれ暴るが基準として本法仙よる埸合 $1 \%$ Procain の 单独使用では持続洔間平均 50 分である。亦麻酥効果が 著明に現れたものは，その持綕時間も長い。

従来の万法との效率の比較：本法の庥醇效果を一般 耳鼻科医によつて行われた良来法と比较することはでき ないが、徉来法は恐らく庥醉効果が甚だ低いであるらと 思われる、攵、本法の效果を䂙究者であり，熟練者であ る野村氏の示主效率と比較することも，逄ずしも妥当で はないがここに氏による集中注射法によつて得た啝酸 効果と対比してみる.

即方効果（H）は詳細な基礎的於究と練習度の高い，野 村氏が僂れているが，效果（H）になると基磷的恠究か ら入こた氏による成績と臨床的効果を重点とした著者法 との差暴は㱠んどなく，效果（十）においいては明らかに 本法の方引゙有利である・斯樣に $(H)+(+)$ 程度の有効 率が幅広く極めて高率で而も安定している点に本法の特
第 2 表 集中泩射法（野村）との比轱

\begin{tabular}{|c|c|c|}
\hline 航酥效果 & 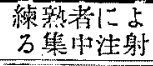 & 本 \\
\hline$(\mathrm{HH})$ & $18.33 \%$ & $13.29 \%$ \\
\hline$(H)$ & $50.00 \%$ & $54.43 \%$ \\
\hline$(+)$ & $18.33 \%$ & $27.83 \%$ \\
\hline$(-)$ & $13.34 \%$ & $4.43 \%$ \\
\hline
\end{tabular}

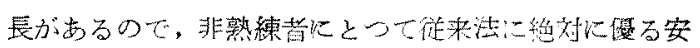
易性と磪実性在与充る所以で南る。

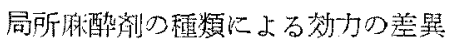

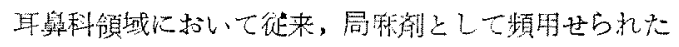
莧剂は Cocain 及び Procain (Novocain) であるぶ, このうち Cocain 柱として表面塗布麻酔剂に用いられ

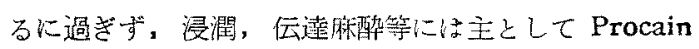
が使用される・最近に至つてこれ等闭㰾の代用品，ある

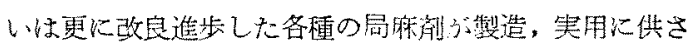
れるに至つた・中でも1942年こ Swedenにおいて合成

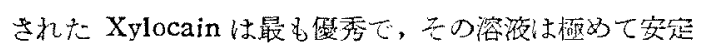
で, 容易に隇菌でき, 毒性低く, 組織刺㦸性むなく, 安 全率仕 Procainに2 倍し，局麻獄としての理想的条件 が满されている、Lundquist等によれれ゙， その効力は Xylocain $+A$ renalin 1 征来の Procain + Adrenalin に比して麻醉の発現率, 範围, 持続時問等いでれる2 倍 万至 5 倍の效力を示すと言い，凡沐る形式の局所麻酔に

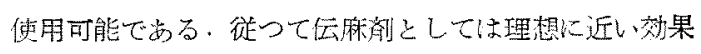
を発挥すると言われている、落者市本法䒠施にXylocai a を応用, Procain とその效力袁比較䄼討した結果次の

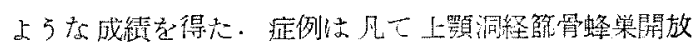

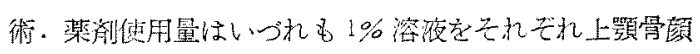
面壁の粘骨膜部 (切開部位) に $10 \mathrm{cc}(+5 \mathrm{cc}$ 以内) 伝 麻化 $5 \mathrm{cc}$, 病变は中等度の症例て方分。

第 3 表 Procain $と$ Xylocain $こ の$ 效打比战

\begin{tabular}{|c|c|c|c|c|c|}
\hline \multicolumn{3}{|c|}{ 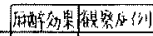 } & 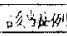 & 4.4. & 信赖限星\% \\
\hline & 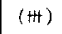 & 22 & 3 & 13.64 & $30.36 \sim 6.15$ \\
\hline & $(H)$ & 22 & 14 & 63.64 & $77.86-45.96$ \\
\hline & $(t)$ & 22 & 5 & 22.73 & $\mid 40.36-12.06$ \\
\hline & $(-)$ & 22 & 0 & 0.00 & $1221-$ \\
\hline & ( $(\mathrm{it})$ & 26 & 3 & 11.54 & $26.29-5.21$ \\
\hline & (H) & 26 & 13 & 50.00 & $|65.28-3472|$ \\
\hline & $(+)$ & 26 & 8 & 30.79 & $4710-18.55$ \\
\hline & $(-)$ & 26 & 2 & 7.96 & $21.56-3.10 \mid$ \\
\hline
\end{tabular}

第 4 表各属を合併して $2 \times 2$ 分割表を作り検討して見 ると（H，H）；(十, 一)の組合放せで $\mathrm{P} \equiv \operatorname{Pr}\{t>$ $1.17\}=0.5-0.379=0.121$ で有意の差をもつてXylocain 
第 4 表 Xylocain, Procain 効丧

\begin{tabular}{|c|c|c|c|c|c|}
\hline & $(\mathrm{HH})$ & $(H)$ & $(t)$ & $(-)$ & at \\
\hline Xylocain & 3 & 14 & 5 & 0 & 22 \\
\hline Procain & 3 & 13 & 8 & 2 & 26 \\
\hline 計 & 6 & 27 & 13 & 2 & 48 \\
\hline
\end{tabular}

がより有効である（他の2つの組合わせでは有急差殆ん

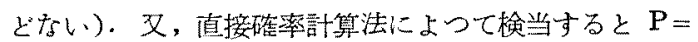

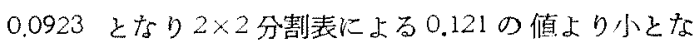
り従つて乍険率 10 と守れば有意差をもつて Xy. は

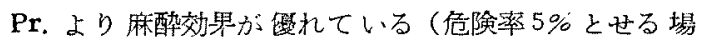
合, 現段階の実験から両者間の有意差は認好難い).

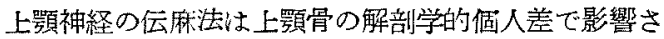
れることが多く，必すしも常に注射針は神絟幹に到達し ない，併し手術の麻酔效果を得るためには神絓幹内への 刺入が絶刘的条件ではない，麻醉効果の発現率の高い方

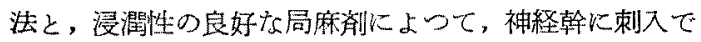
きなくとも，充分目的を澾し得るものである。

本法に Procain 汇代つて Xylocain を使用すること とより, 従来見られなかつ穴安易, 確実な神経遮断効果 を得らる〉ものと思う

\section{第3 章 出血に及ぼす影響}

出血抑制効果：Braum (1911)，野村氏(1952) 等は翼 口蓋忿入口部で薬液を注出することにより，A. Maxillaris int. を狭窄せしる，手術時の出血を少量にすると 述べている、その出血抑制機転が単なる血管狭窄による るのか否かはしばらく拉いて，上顎神経伝麻を施行した 症例で手術特の出血が抑制されることは愿々経鍳するこ とでむる・著者の症例で観察した結果も著明な出血抑制 効果を認めることができた。表は同一人に拉いて両側の 手術をした場合, 主として第 1 回手術に括ける成績につ いて観察し且つ出血量は手術時の肉眼的観察によつたも のである。

第 5 表 出血抑制效臬

\begin{tabular}{|c|c|c|c|c|}
\hline 出血程㛺 & 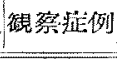 & 該当症例 & 百分篗 & 信 顀 限 哭 \\
\hline (I) & 80 & 9 & $11.25 \%$ & $18.55 \sim 6.88 \%$ \\
\hline$(+)$ & 80 & 32 & 40.00 & $49.23 \sim 31.57$ \\
\hline$(H)$ & 80 & 25 & 31.25 & $40.23 \sim 23.64$ \\
\hline$(\mathrm{HH})$ & 80 & 14 & 17.50 & $25.76 \sim 11.82$ \\
\hline
\end{tabular}

（士）は極少量の出血：（）は少量の出血，(H)は中 等度の出血，(H) 俈中等度以上の出血を示す
観察症例は上頸洞手術（大部分は経洞的に篩骨洞も開 放）例で，術前に止血凨としては Thrombogen $5 \mathrm{cc}$ 皮 下注射を施行，条件を同一とした。

肉眼的観察によつても䄪半数例に施術洔出血の減少を 示寸。但し第5 表観察例は出血量の量的計測に上つたも のではなく 且つ切開, 刺入部露出に至るまでの出血量 をも含えでいるので，出血抑制効果そのものを示するの でない。

以上の伝麻を施行した場合の肉眼的な出血量減少の成 績を非伝麻例の場合と対比するとより明膫汇出血抑制を 認めることができる。非层麻手術例について同一条件下

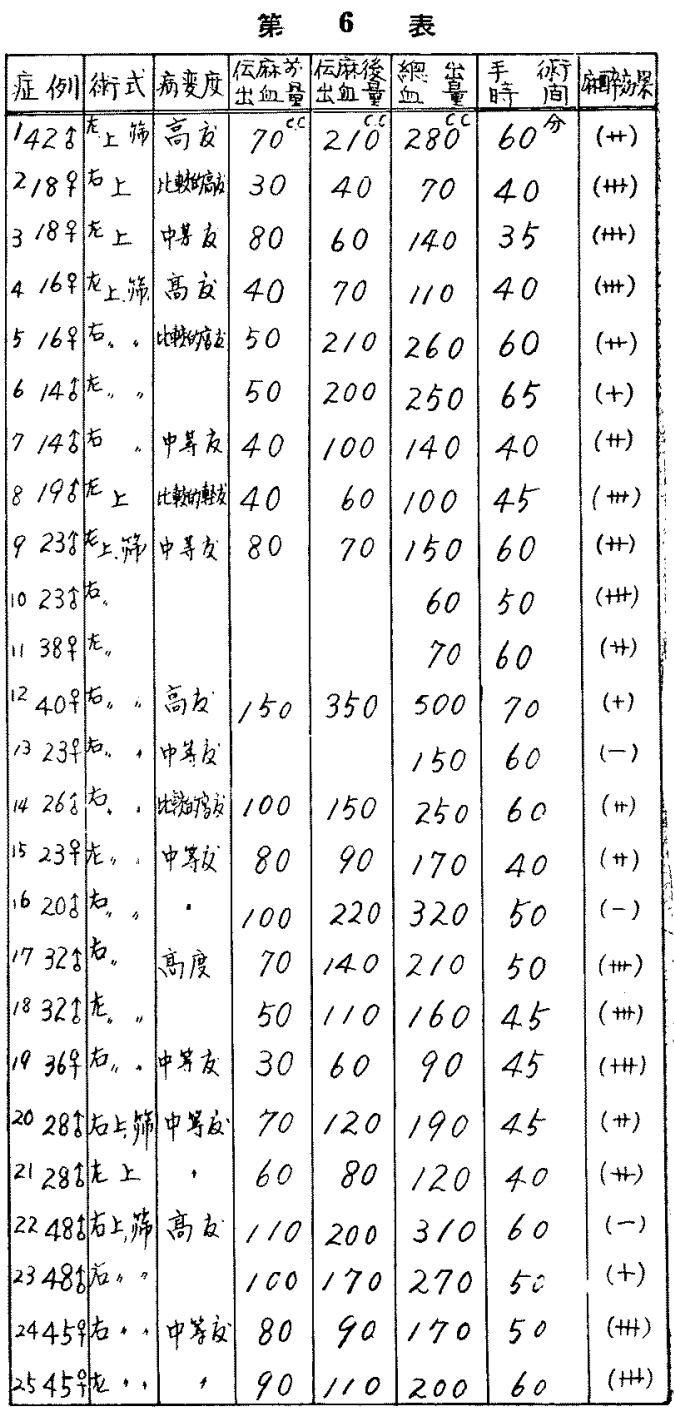


の肉眼的観察での成續の大略は25症例についてみると (土)ca $6 \%,(+)$ ca $20 \%,(H)$ ca $51 \%,(H)$ c 223 \%である・な扰，従来の上顎洞手術の場合における平均 出血量は各種の外科的手術の場合に比して案外に多量な 数值を示すことを認めることができた（但し肉眼的短察 程度からの推定）。

饮に同一条件に和いて层麻前後の出血量，総出血量及 び手術時間について, 直接法（吸引塯中の血液量計测と

Wangensteen. 1942, の Gaze 重量法定併用, 且つ吸引

器は2 基を使用，血液以外の液体の混入を避けた）によ つて量的に計則せる 25 側から得た出血抑制効果は第 6 表に示主通りである。

（上）は上顎洞根治手術（Luc 氏法に準ず）（上，籍） は上顎洞経由節骨洞開放術を示す

上素定分析すれば解る上うに，出血量の少ないことが 伀麻との\&のに由来寸ることは，伝麻施行老境として明 らかに出血量が急激に娍することから充分に了解でき る。伝麻前までの時間は凡そ10 分前後であるから，伝 㑣後の単位時間出血量は橄好少量と見做される。

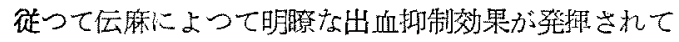
いることが艧る。

手街時間は掻いて短縮するよ5な試みはせず，出血が 少量であるのき利用して反つて丁密に手術したが艺れで る手術時間は短䌅されている。

第 7 表 单位特間內出血量

\begin{tabular}{|c|c|c|c|c|}
\hline & 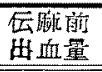 & $\begin{array}{l}\text { 层覆後 } \\
\text { 出血量 } \\
\end{array}$ & 手少時間 & 倩 \\
\hline 证例平均 & $71.3 \mathrm{cc}$ & $132.2 \mathrm{cc}$ & 51.19 & \\
\hline $\begin{array}{l}\text { 每10分間| } \\
\text { 出血量 }\end{array}$ & $71.5 \mathrm{cc}$ & $33.05 \mathrm{cc}$ & 10分踏位 & 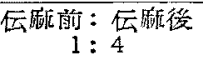 \\
\hline
\end{tabular}

本表によれば凡そ1/2 量の出血娍少が伝麻後に認めら れる。

出血抑制と麻酥効果

上顎神経伝庥施行後に出血抑制效果が著明に出現する ことは上述の通りであるが，多数の伝麻研究者が注目し た事はこの出血抑制作用が麻酔効果と関連していること である・著者の开究によつても明らかに比例関係が認め られている。

以上の原表から各層を合併して $2 \times 2$ 分割表を作り各

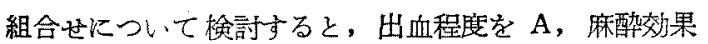
を $\mathrm{B} て ゙$ 表わし, $\mathrm{A}( \pm,+, \mathrm{H}),(\mathrm{H}), \mathrm{B}(-),(\mathrm{H}$ ， $H,+） の$ 組合せでは $\mathrm{P} \equiv \operatorname{Pr}\} t>2.74\}=0.5-0.497=$

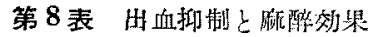

\begin{tabular}{|c|c|c|c|c|}
\hline \begin{tabular}{|l|} 
観察 \\
症 例 \\
\end{tabular} & $\begin{array}{l}\text { 麻 醉 } \\
\text { 効 果 } \\
\end{array}$ & 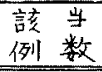 & \begin{tabular}{|ll} 
出 \\
程 度 \\
\end{tabular} & 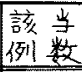 \\
\hline 80 & $(H)$ & 10 & $\begin{array}{l}( \pm) \\
(+) \\
(H) \\
(H+H)\end{array}$ & $\begin{array}{l}4 \\
4 \\
2 \\
0\end{array}$ \\
\hline 80 & $(H)$ & 37 & $\begin{array}{l}( \pm) \\
(t) \\
(t+) \\
(+H)\end{array}$ & $\begin{array}{c}3 \\
16 \\
13 \\
5\end{array}$ \\
\hline 80 & $(t)$ & 27 & $\begin{array}{l}( \pm) \\
(+) \\
(H) \\
(H+H)\end{array}$ & $\begin{array}{c}2 \\
11 \\
9 \\
5\end{array}$ \\
\hline 80 & $(-)$ & 6 & $\begin{array}{l}( \pm) \\
(+) \\
(H+) \\
(H+1)\end{array}$ & $\begin{array}{l}0 \\
1 \\
1 \\
4\end{array}$ \\
\hline
\end{tabular}

$0.003, \mathrm{~A}( \pm),(+, \mathrm{H}, \mathrm{HH}), \mathrm{B}(\mathrm{Ht}),(\mathrm{H},+,-)$ の組合过では $\mathrm{P} \equiv \operatorname{Pr}\{\mathrm{t}>2.54\}=0.5-0.494=0.006 \mathrm{~A}$ $( \pm,+, H)(H), B(-,+),(H, H)$ の組合せて $\mathrm{P} \equiv \operatorname{Pr} .\{\mathrm{t}>1.93\}=0.5-0.473=0.027 \mathrm{~A}( \pm,+),(H$, H), B (H)，(H, +. 一) の組合せでは $\mathrm{P}=0.052$ て

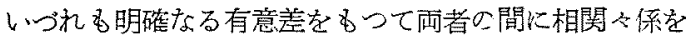
詮める。

亦, 出血程度士，十，H，Hに対して仮に 1，2，8，

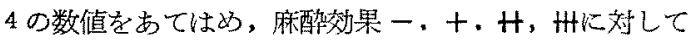

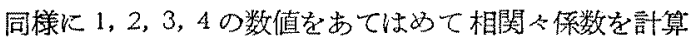
すれば

相閔保数 $\mathrm{r}=-0.3665$

検定す光ば $t_{0}=3.47 \quad t_{78(0.05)}=1.99<3.47$ で相関伱数 は有意ですり，危険率 5\%で出血程度と麻醉效果とは明 らかに相関ミ係にある（麻醉効果が大なる程出血量は少 w).

\section{第4章 血圧，脈擭，呼吸数に及ばす影徘}

一部の動物実験による种究を除いて，実地臨床上，上 顎神経遮断により血王, 脈搏, 及び四吸等に起る变動に

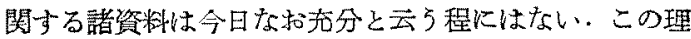

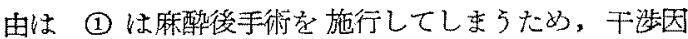
子が複雑多皮となり，純粋な伝麻による影響をとり上げ ることが困難になること（（2) 真の意味に和ける上顎神 経完全遮断の礁認が臨床的には至難であること（幹内剂 入と言い，神経便整と言い，臨床的に道断成否の判断は 厳密には推定の範国を旦ない). (3) 所謂，アカデミッタ 
を価值判断の恶㑯向の一つとして，基淮的単一性が過重 され，干洗因子纪富を臨床的実態に関する探究が意識的 に廻避され，軽視される結果，看過されてきたこと・な どに由来すると思

上䪽神経遮断の血圧等に及ぼす影響の研究には勿論基

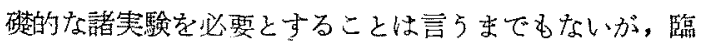
床的には一概に上顎神経云達麻醉と称しても必ずしも神 経主幹麻醋とは限らない，局麻珴が充満される少さな骨

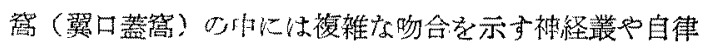
神経系に属する翼口蓋神経節等も存在し，これ等神経系 の麻醉も同時に起る篔である・従つてこれ等を介して血 压等にも何等かの影饗が汲ぶ事を考慮しなければならな い. 且つ從来時汇認められる上顎洞手術後の異常疼痛の 持続や浮㺿の出見，又はS Sulder 氏の神経痛の発来など

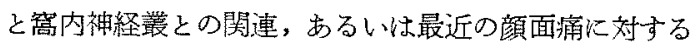
翼口蓋神経節の経洞摘出つ試及 (David L. Poe 1949)， 㕛は耳鳴の治療法としての同神経節の経洞的摘山（後滕 敏郎教授 1955）等が，所究され，上顎神経や翼口蓋神経 節の遮断に関する臨床的意義は殊に重視されてよい筈な のに，今日な括をの及活可影響については僅か汇副作用 的効果の検当がなされているに過ざない.著者は純粋な 生理学的乃至薬物学的研究としてぶはなく，笑地臨床的 に上頻神経伝麻が上頻骨手術に施行せられた場合の，手 術中に見られる血圧等の変化を患者に就いて追求して見 た。

観察例に対しては総て迷妄麻醋は行わず，固有鼻胵内 の清浄の外江無処置, 粘膜切開部には $1 \%$ Procain 欢 㳉 $1 \%$ Xylocain の浸潤麻䣲学 $10 \mathrm{cc}( \pm 3 z \mathrm{c})$ 使用, し止血凨としては一律に Thrombogen $5 \mathrm{cc}$ 皮注，その 他の不要な操作保一包行なすず条件の均一を計つた。

採用した症例往麻酔勃果 (H) 程度以上, 出血量は (十)乃至 (H) 以下のものだけとし，出血による影響を 余り考慮しないで良いものを選んだ。

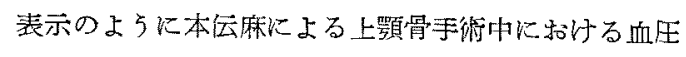
その他の変動は, 上算, 下降共いられも生理的動摇の範 囲内にあり，有意の病的動摇法認められず，実施上障害 となるような影響视認められなからた。

伝床を行なわない局麻例に比すると，伝麻例では血生 が手術経過中を通じて可成り低いが，その原因がどの程 度神経遮断に因るものか問題である。一般儿手術時疼痛 によつて血圧は上昇する傾向がある，従つて有痛手術に 比して無痛手術ではある程度出血が抑制されるかも知れ ず，更に血圧にも影響を及ぼすと思われるがその程度を

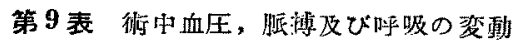

\begin{tabular}{|c|c|c|c|c|c|c|c|}
\hline 迢 例 & 術直前 & (I) & 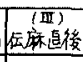 & $\begin{array}{l}107) \\
10 \text { 分後 }\end{array}$ & 20今後 & $\begin{array}{c}(7 D) \\
30 \text { 後 } \\
\end{array}$ & (viI) \\
\hline NO & $8 \sim 68$ & $110-70$ & $1 / 4 \sim 70$ & $110 \sim 56$ & $106-54$ & $112-60$ & $123-7$ \\
\hline & 80 & 70 & 80 & 36 & 64 & 76 & 82 \\
\hline & 100,70 & $110-70$ & $108-65$ & $100-60$ & $8-57$ & $76-58$ & $\frac{-}{108-6}$ \\
\hline$(2) / 95$ & 110 & 106 & 126 & 100 & 100 & 108 & 108 \\
\hline W & - & - & - & & - & & \\
\hline & $4-84$ & $0-92$ & $42-94$ & $128-88$ & $124-86$ & $126-90$ & $112-2$ \\
\hline 231 & 66 & 64 & 60 & 66 & 64 & 64 & 64 \\
\hline No & 13 & 16 & 78 & 18 & 78 & 16 & 16 \\
\hline & $110-84$ & $122-86$ & $126-88$ & 124.90 & $120 \cdot 94$ & $16 \sim 94$ & $\mid 36-10$ \\
\hline 231 & 78 & 24 & 7 & 78 & 70 & 72 & 64 \\
\hline (7) & 18 & 18 & 20 & 20 & 18 & 18 & 20 \\
\hline & 4.86 & $1-82$ & 142.88 & $126-86$ & $222-84$ & $114-84$ & 38278 \\
\hline 198 & 82 & 90 & 94 & 96 & $\begin{array}{l}46 \\
18 \\
\end{array}$ & $\begin{array}{l}92 \\
16 \\
\end{array}$ & 68 \\
\hline
\end{tabular}

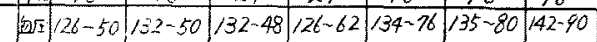

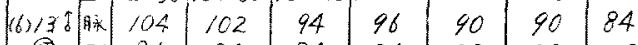

\begin{tabular}{|c|c|c|c|c|c|c|c|c|}
\hline (a) & ofFas & 21 & 24 & 24 & 24 & 23 & 22 & 9 \\
\hline & & $20-7$ & $124-76$ & $1 / 32-80$ & $122-84$ & $122-90$ & $130-92$ & $144-48$ \\
\hline & & 100 & 118 & 116 & 120 & 108 & 114 & 112 \\
\hline D) & $0 \bar{y} \times g, 8$ & 19 & 20 & 22 & 22 & 20 & 20 & 20 \\
\hline & 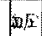 & $120-72$ & $140-84$ & $142-86$ & $130-82$ & $129-88$ & $126 \sim 90$ & $\frac{-1}{124-88}$ \\
\hline $\begin{array}{r}(8) / 5 \\
(8)\end{array}$ & An- & $\begin{array}{l}96 \\
18\end{array}$ & $\begin{array}{l}96 \\
24\end{array}$ & $\begin{array}{r}112 \\
24\end{array}$ & $\begin{array}{r}104 \\
21\end{array}$ & $\begin{array}{r}114 \\
20\end{array}$ & 106 & $\begin{array}{l}98 \\
20\end{array}$ \\
\hline & & & 168 & $88-7$ & $30-78$ & $30-78$ & 2 & $102-64$ \\
\hline
\end{tabular}

\begin{tabular}{|c|c|c|c|}
\hline 脉 & 120 & 124 & 126 \\
\hline
\end{tabular}

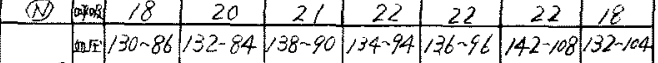

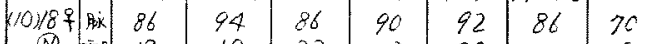

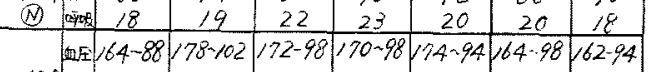

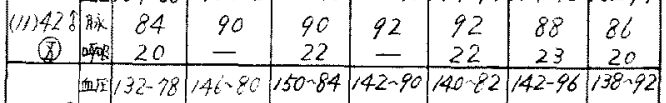
112)199 \begin{tabular}{|c|c|c|c|c|c|c}
\hline 98 & 116 & 118 & 116 & 118 & 110 & 90
\end{tabular}

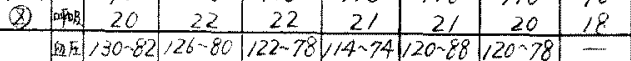

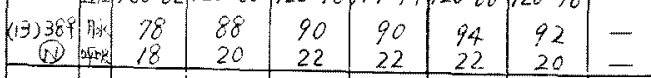

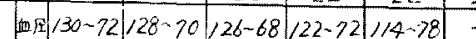

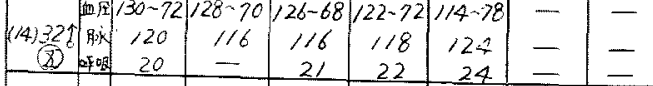

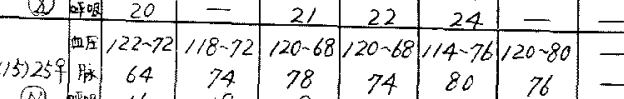

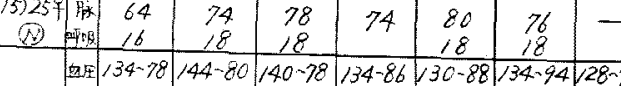

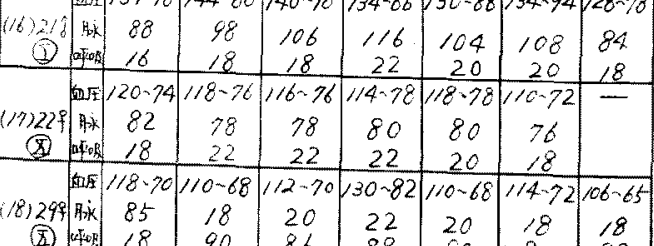

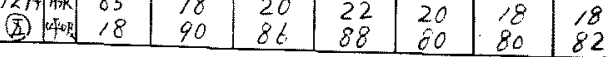

解明するのは困難である。唯本伝麻法の場合 (1) 手術 は終始無痛に経過するにも拘らず，伝麻注射施行を境々 して比較的はつきりした最高血圧の下降, 最低血珐の上 昇が球現する事実と，(2) 副作用の章において述べるが 
如き 2,3の自律神経症状（散瞳など）の出現から，この 血生の変化は単に疼痛の有㷮因るものでない事だけは 磼実である。

第 10 表 血圧の婆動曲楾

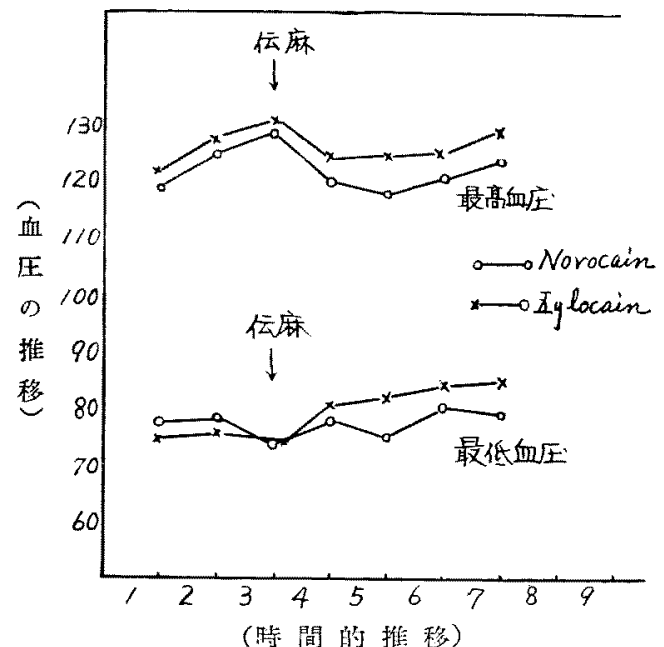

なお，使用局库昘による美違は著明ではないが，

Procain Gruppe $\sigma$ 方が Xylocain Gruppeよりも全 経過を通じて 低血圧を示すが，その桇動の Type は殆 んぞ同じである鹈10表，曲線表示汇際して第9表中 No.11 42j \& Xylocain 便用应例は腎炎, 高血圧庭を合 併していたつめ年殊例として曲線作製に当つて除外し t).
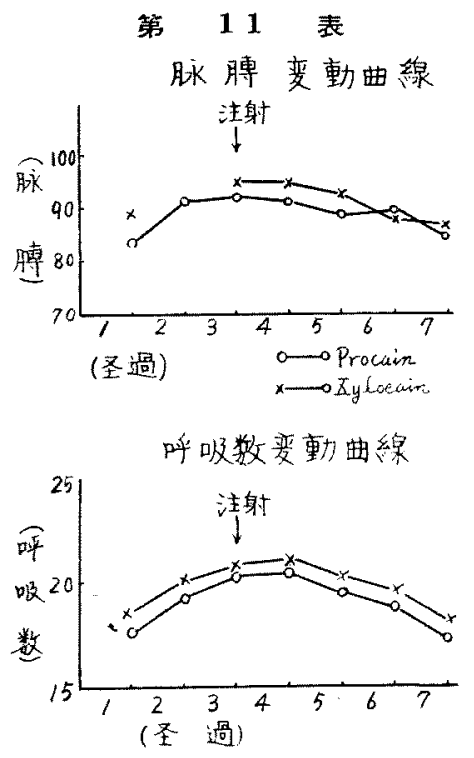

脈搏，呼吸に対しても全く满的異常を起すことはな

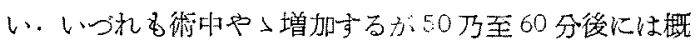
社術前に復する。

Procain-Gruppe そ Xylocain-Gruppe との社比では Xylocain 症例がいつれも多少増加するが経過や相漛に は大差を認めない。

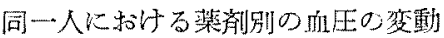

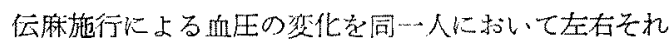
ぞれ一侧は Nvocain (Procain)，他側は Xylocair 庥 醉を施行した症例について観察した結杲，次表の成績を 得た。但し症例は凡て上㖽洞経由管骨洞開放術で, 使用 蒋量, 病変程度, 出血量, 手術時間, 年令 $(18 \sim 30$ 才) 等が秘权同一条件にあると晃做し得る症例を選出, 稓察 したるのである。

局麻郕使用量は上顎骨浐面壁の粘，骨膜下(可開部位)

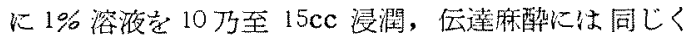

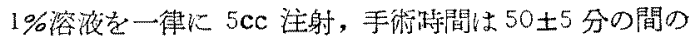
症列で如る。

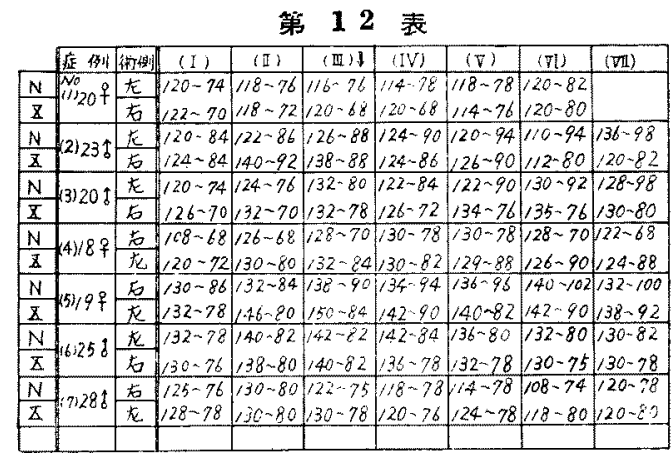

結果は上表の通り，一般的な薬成斺による血圧の推移 と殆えど同赤に，若干 Procain (Novocain) 使用例の

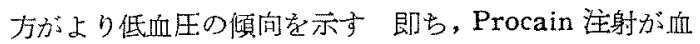
压学や小下降せしめる傾问を有寸ることは個人的差異に よるばかりでなく 明らかに Procainその車の小影響 が合をれていること京示す。

しかしながらその影耗の程度は偉少な导のであり，先

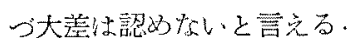

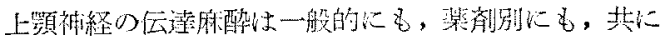

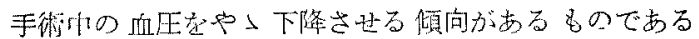

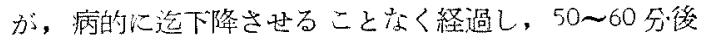
には正常に復する(ウインクミンの倡用扎より暴常に病 的下降学示扎と多し)。

\section{第 5 章 副作用について}

副作用を起す最も多い原因は，(1) 針の刺入が梁すぎ 
ること，(2) 针の主軸や刺入方向が，ことに失状面に対 してそれること．更に (3) 灌壁性を失することにある。 これを避けるためには充分慎重に注射を行らことが最も 大切で, 夫れについては第 1 編の刺入による危険とその 防正法の項に詳細に説述した。

本章においては犆接の刺入の過楞による障碍を除い て，著者が本法を施行した症例 173 側中に見られた，多

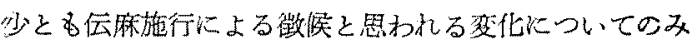

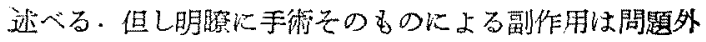
として手術に因るか，伝麻によるか明磪でないるのは一 応これ究含めて記載した。

上顎神経伝麻の副作用についてての交解を見ると，

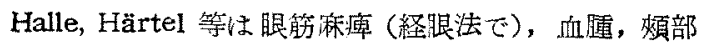
腄脹等学举げているが, その発生率は比䡆的低い, 最近

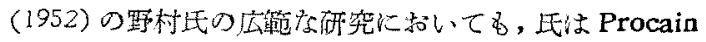
注射によると思われる激しい頭痛の1訽を学げているに

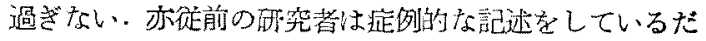
けで, 観察的, 統計的記速や, 副作用の双以つての考 案記裁は殆えどない.本法によつて著者の手術例に詯め

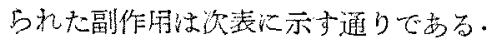

第 13 表副作用の種類孔ての頻尤

\begin{tabular}{|c|c|c|c|c|}
\hline 禈 & 森罢症例 & 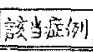 & 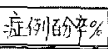 & 信赖限量％ \\
\hline 湟 & 173 & 23 & 13.29 & $18.20-8.70$ \\
\hline 頭部然否 & 173 & 9 & 0.52 & $0.89-0.31$ \\
\hline 猈面シどL感 & 173 & 6 & 0.34 & $0.67=0.19$ \\
\hline 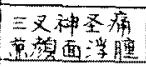 & 173 & 2 & 0.11 & $0.35-0.04$ \\
\hline 该後出的多量 & 173 & 7 & 0.40 & $0.74 \sim 0.23$ \\
\hline 散曈上褑福 & 39 & 3 & 7.69 & $18.21-3.48$ \\
\hline 数 & 39 & 2 & 5.13 & $14.91-2.08$ \\
\hline 口唇、ルペス & 39 & 3 & 7.69 & $18.21-3.48$ \\
\hline 耳周金鄫 & 39 & 3 & 7.69 & $18.21-3.48$ \\
\hline 流㴑過多 & 39 & 1 & 2.64 & $1.12-0.89$ \\
\hline
\end{tabular}

(1) 特に副作用纪注目して観察するとや小多数に見ら 机るぶ，机は手術そのものに由のて起る症状があ

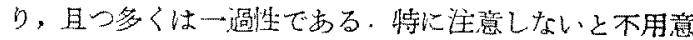
に看過されて了580が多い，事整散膰等は比較的多数 の症例を重福る远看過されていた副作用である。

(2) 副作用の持続時間. 㱠んど凡て一迫性である・最

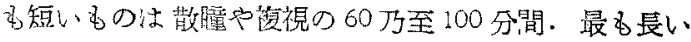

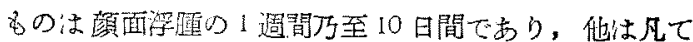
数特間万至数10 時間である。
(3) 頭痛及び頭部熱感は一般にも術後に見られるるの である、㫿 24 時間以上持続したすのを一店本层床法の 影響もあり得るだろうとして挙げたが，激痛を訴えた者 は2例過ぎす，他はいつれる軽いるので，䜌て48時 間以内に消失している。

(4) 副作用の多くは顏面神経, 三羿神経出るいは自律

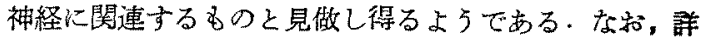
細以観察すれば，一過性の舅内症状などあるものと想喚 されるが，局所の術後性反店やタンボン等に㩊されて不 明である。

（5）副作用の全体を通じてその出現率，应状，持続時 間等いら゙れも比較的軽徽なものであり，本法による害 としてとり挙げる程度のものではない，且つこれらは上 頻神経层麻法に共通の現象であり，むしろ著著法は他の カ法，ことに経眼法などに比して，その出兒率は低いと 思われる、永綄的な副作用は㫮無である。

散朣については出沜，血圧の変動なとと共に上下若干 の考案を加える。

小括

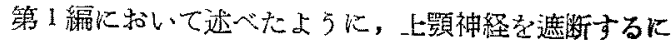
は翼窝で行はなければできない。この小骨简内には多数

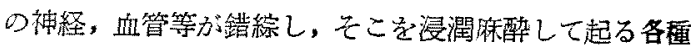
の作用（出血抑制，血圧の㚆趿などを含む）は，単なる

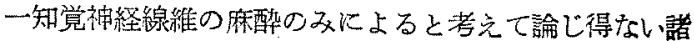
条件が含まれている、こっに本法に附随する副作用等を 2，3探りあげて文献並びに基碳的事実から若干刀臨床的 考察を試みる事にする。

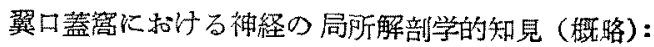
上顎神経は半月神経節で第一枝，第三枝と分れ，三叉神 経第二枝として出て中頭蓄膑より正円孔を通過し翼窝に 入る。こで主幹は眼窠下神経となつて下眼窝裂より眼 窝底に沿い, 途中眼集下動脈と共になり, 顔面の眼简下 孔に出現する，翼窝内に拁いては三本の主要な分枝を 出している. 即ち，（1）煩骨神経，（2）翼口蓋神経， （3）上荬槽枝である。これ等はそれぞれの部分の知覚枝 である之共に，翼口蓋神経節や顔面神経，又は顎鲗部の

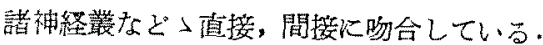

出角, 血王, 副作用等闻閔連する事として注目される のは、この骨蜜には自律神経節である翼口蓋神経節が存 在することである・上頻神経住骨营内において数条から なる翼口蓋神経を出し，これ等の神経山翼口蓋神経節を 通つて鼻口蓋神経となり，分れて後舅神経，大口蓋神経 等となる。一方この神経節は上頻神経の淔下゙て Vidian 
管よりでた同名の神経線維を受けている。この神経注植 物性神経であり，顔面神経の祢神経節から分れた大浅岩

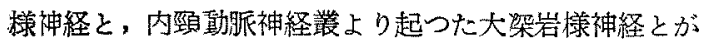
一緒になつたもので, 前者は副交感神経系であり, 後者 は交感神経采である、翼口蓋神経節はこの神経と，翼口 蓋神経との吻合部で，錯綜した神経缐維間に散在する節 細枹から成立している (Müller).そしてこの神経節を 通過寸る神経線維の中この節細胞に終つているるの活副 交感神経缐䊒のみであつて，他の交感神経及び知覚神経 線維は単に通過するのみと言われている。翼口蓋神経節 の形熊については従来の成書にあるような特有な膨捀体 を示するのではないと言う (Müller Daoid L. Poe, 後藤 (敏) 授等).

唧亏，この神経筑任副交感神経性と看做され（呉教 授), 線維恃後鼻及び 口蓋神経と共に下降して 鼻腔内に 分布し，一部の分忮付再び上顎神経纪入り観骨枝を経て

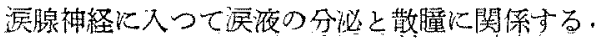

潩口蓋神経節症状

斯様にこの神経節は一力に和いては上顎神経や顔面神 経などと，他方では自律神経系と䦙連しているため，そ の刺战乃至麻酥性当然隀々な三叉神経, 顔面神経及び自 律神経症状を起すことが考えられる．Ruskin はその刺 戴虚状を 4 Aff ection Symptoms として，(1) 三文神 経庭状, (2) 知賞性顔面神経症状, (3) 绞感神経定状, (4) 局所性鼻神経定状举紊ている. 又 Haek 2 angioneurotische Störungen として (1) 外鼠皮虔の発沶, 浮腫, (2) 急性限呞性浮重, (3)眼定状, (4) 胘篗, 喕 吐 ( $x=x ー ル$ 症状), (可) 袖経痛等考举げている. S1uder 4 Sympathetic syndrome (Iowerhalf headache) $z$ nasociliaty neuralgia (neuralgia of nerv. ethmoid. ant) とを举牧ている。究の他 Heymann, Killian, Hoffman 等の研究もいづれる鼻神経㱏状と自 律神経症状との関連性を述べている。

上記の知見からも伝麻化際して出見する各種の湑状を 考察すると，注射㨁媵から認为られる落明な出血刀抑制 は, 一つ怯 Matas 氏の言弓如く, A. maxi.laris int.

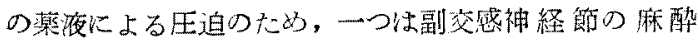
による血管脑㖘の抑制のためと考えられる。岁るいは伝 麻汇よる自律神経系及び知賞神経系の麻䣷が，中枢に反

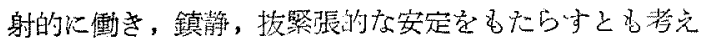
られる、そのために無溜效果も補和れ，術中の血圧の軽 度な下降を招来与尚むのと考光られる。

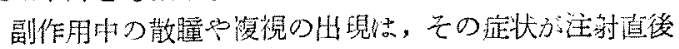

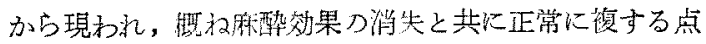

から恐らく翼口蓋神経節麻醉の結果, 副交感绅経譏能の 減退するためと考察される。な蛙，その出現の程度虫骨 简内の各神経, ことに自律神経系の個人的の感受性の羑 異に基つくくものと考えられる。

頭痛, 神経痛, 浮連, 術後出血等の副作用は, 決して 術中万至術直後には出現好ず，麻酔効果が完全に消失し た数特間後に現われる。この事䒠仗これ等の副作用が麻 酔そのものに直接伴うものではなく，Ruskin，Haeck 等の言了所謂,刺㦸定状であると考光るのが妥当である。 それが有害な病的㔀㦸でないことは，これらの症状が多 くは数持間万至は数 10 特閒の一過性経過を示方事から 推定し得る。

\section{第 6 章 考按}

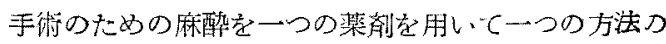
みで行5やり方は，既仗古典的になりつつある。現代の 冽酔学の立埸恃麻酥医学々して專問的独立を見る程に福 維多岐な発展をとけ゚つ入ある・ある種の手術が，たとえ

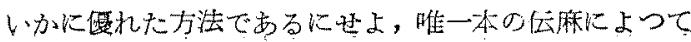

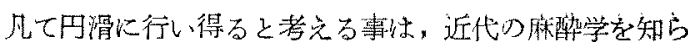
ざる者である。

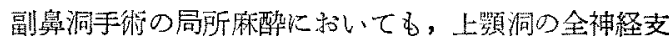

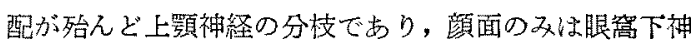
経で支配され，鼻内汇前後の節骨神経及び翼口蓋神経 節よりの分枝が分布している．従つて先つ鼻粘膜を麻䣲

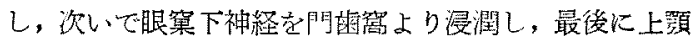

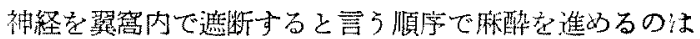
当然である・徒つてこの際の上䫇神経伝䏫法法独立した 一つの伝麻法として考学る可きではなくあくまで上顎 洞手術に対する楾合麻醉法の一部としての告義を有する ものであると考觉る。

（H）宠の麻酩効果の意義

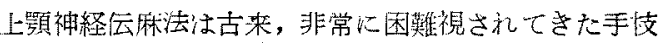

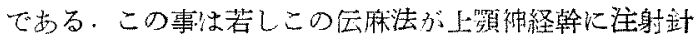

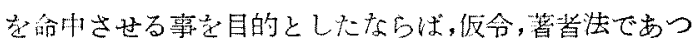
ても, この意味での上㣌神経云麻法法今日な和至難な手

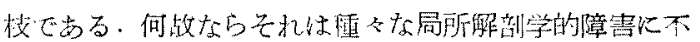
可避的化制約されさるる觉得ないかからでする.上影神経伝

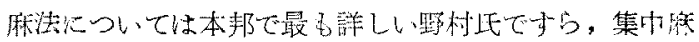

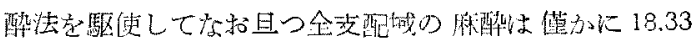

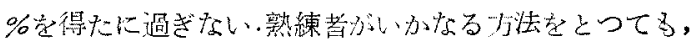

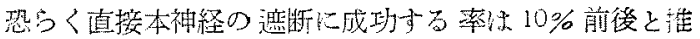

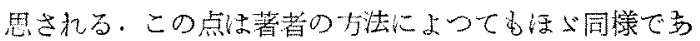
る。しかしながら既述の如く我々の実地監宋上の目的つ 
た奴，必要且つ充分な条件を充す麻醉効果の薄得には， 必ずしも在射か、占援神経幹仁的中する事を必要とはしな い舟痛手術施行のためにに表示した麻醉炏果(H)程度 の矨力て充分に目的を袁し得るものてあり，而むこれは

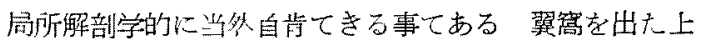

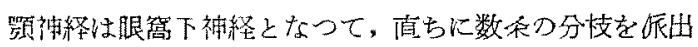
し，これらの分忮は上顕同外側壁に俗つて下行し数個の

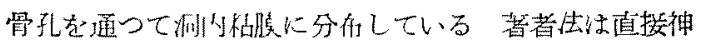

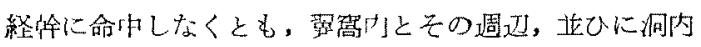

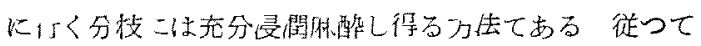

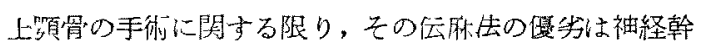
への值接命巾率よりも，奉地臨床上に必要な程度の麻醉 效果によつて判定されてしかる可きであるこの誏味て

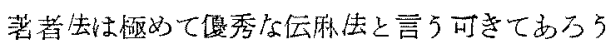

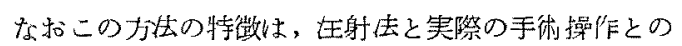
調和を巧妙にとつたつめ，手術に必要な大けの或で，

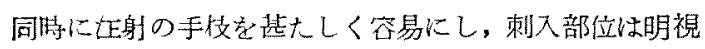

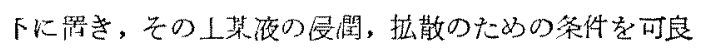
タらしめ，よつて効果老碳実にしたものて，実地臨床上 の留求是最も多く莎した良法てあると考古る

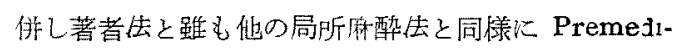
cation を蛏視することはてきない病者の或受性の立 堨からも，本失施行に先立つて Morphin, Fantopon, Phenobarbital 等による基礎休醉 (Basal anesthesia), するいは前麻酝 (Premedication)を施行することは患 者上化静にし, 不安, 恐作走の之き, 局烌郕手手術の刺

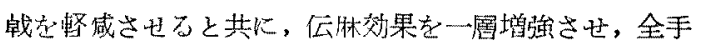
術を安定した队態て遂行するために是非望ましい事であ る 害際上Premedication の存盘の差暴は著明である

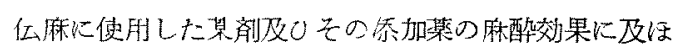

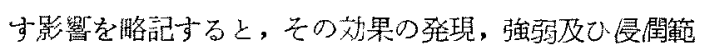

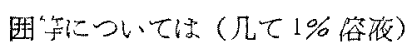

Procaın $<$ Procain + Adrenal $ı<$ Proca 1 + AdrenaIn $\mathrm{A}+$ Hyalurondase

Frocain + Adrenalın - Xylocain $<$ Xylocain + Adrenalın Xylocain $\vdash$ Adrenalın + Hyaluronıdase の順てあ

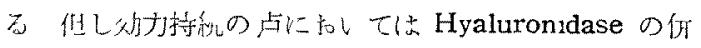

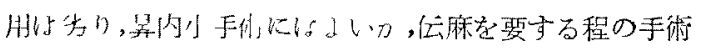

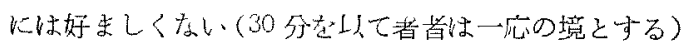
Hyaluronidase 仿月のま入效果持続を計つて Adren

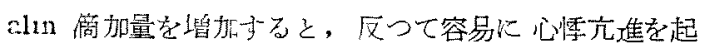
し四却することを゙綮した

著者经の臨床的実地は下記の通りてある

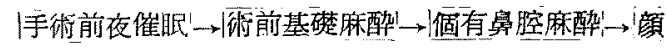

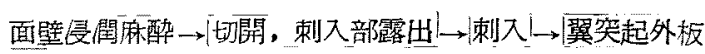

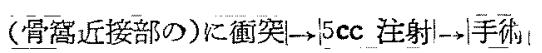

(注射局麻剤は主として $1 \%$ Xylocain +Adrenalın) この際に出現する局麻的 (H) 效果㥩著明に增強され， 殆んと（HH）効果との実際的差異はなくなる

航栐な実際的力庄を慎重に行兄は容易, 砝実に安全な 無痛手術か始めて遂行し得るのである

かくして今日まては一般的価值の乏しかつた上频神経 伝墶麻酔佉を，初心者を含めた一般耳鼻科医に，充分の 効果をむつて曾㴜化し得るものと信する次第である

結 語

本編においては第 1 編代迈へた通りの著者の工夫考按

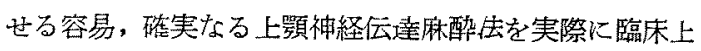
に応用せる場合の床醉効果, 出血, 血圧, 脈搏, 呼吸飞

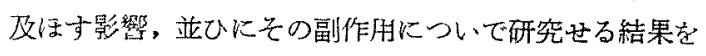
述一た

\section{研究の対象は主として圖性副真洞炎手術である}

砎究の結果は臨床上優れた珠醉効果を発揮し, 同時に 出血を抑制し，血压，脈搏，吅吸等に何等有害な影響を 与えす，且つ有害な副作用も㱠しど伴わない伝麻丢てあ り初心者にも充分に佸用し得る容易，確実なる上顎神経 伀羍麻酔佉であることを種々なる研究結果から証し得た と信ずる

\section{主要参考文献}

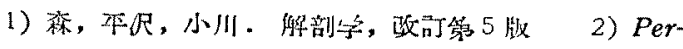
nkopf Topographische Anatomie IV Band 3)

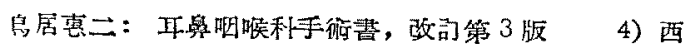

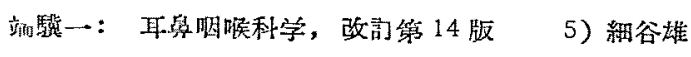

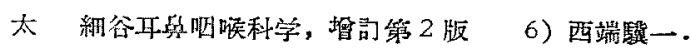

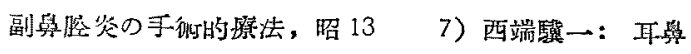

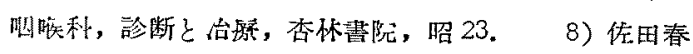

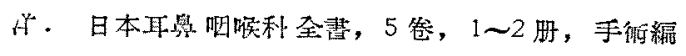
9）只, 中中是侓神経系, 克践堂, 昭 19 10) 冲

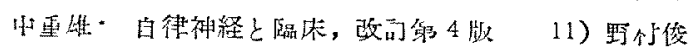

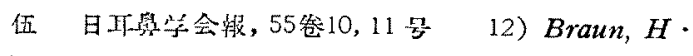
Uber (1e Lokalanaesthesie bei Operationen im Tr gemınuogebiet (Dent Zeitschrift fur Chur III B 1) 13) Derserbe: Uber Behaudlung der Neuralgie des II u III Trigemınu astes mit Alkohol1njektion (Deutsche med Woch n schrift Bd 52, 1911) 14) Hartel - Die Leitungsanasthesie $u$ 
Ingectionsbehandlung des Ganglion Gasseri u. d. Trigeminusstämme (Arch. f. Klin. Chir. Bad, 100, 1912). 15) Offerhaus: Teehnik d. Injection in d. Trigeminusäste (Arch. f. Klin. Chir Bd. 92, 1910). 16) Hirsch: Lehrbuch d. Localanästhesie d. Ohres u. d. ob ren Luft u. Speisewege 1925 . 17) $\mathrm{Bl}$ umental: Zur Lokalanaesthesie d. Oberkiefer operation (Berliner Klin. Wochenschrift Bd 11, 1914). 18) Sirher: Die Anatomie in Technik d. Injektion am Stamm d. 2 u. 3, Trigeminusastes (Öst. Zeitschr. f. Stom 1919). 19) Lederer: Diseases of the Ear. Nase \& Throat 1952 (符6 版)。 20) 结

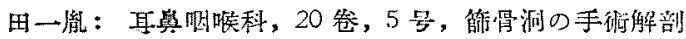

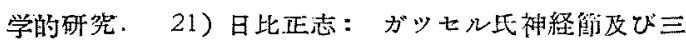

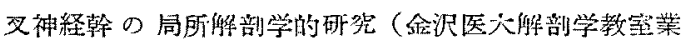

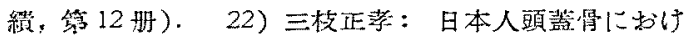

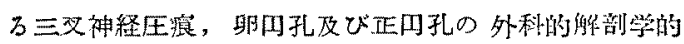

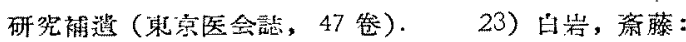

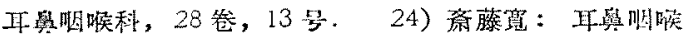
科, 28 兊, 8 号. 25) A. Koblanck: Die Nose als

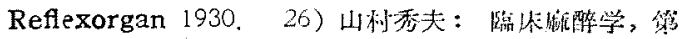
2 织, 炤 30. 27) G.P. Pitkin: Cunduction Anesthesia, Lippincott Co. 贘 2 牧. 28) J.C.B. Grant: An Atlas of Anatomy 1951. 29) E. Haas: Zeitschrift f. Larg. Rhin. Otol. u ihre Grenzgebiete,

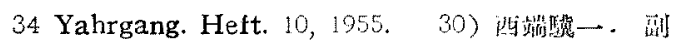

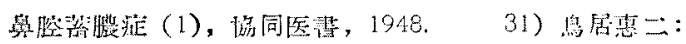

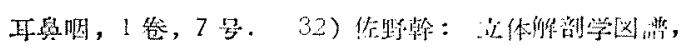

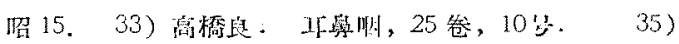

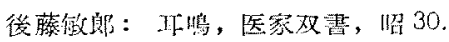

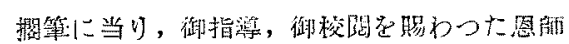

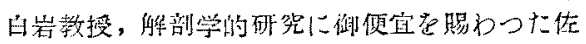

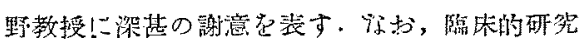

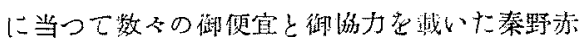

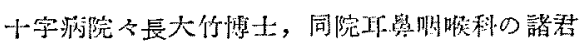
に厚く謝意を琵す

（原和到碟=昭利 32.9 .20 日）

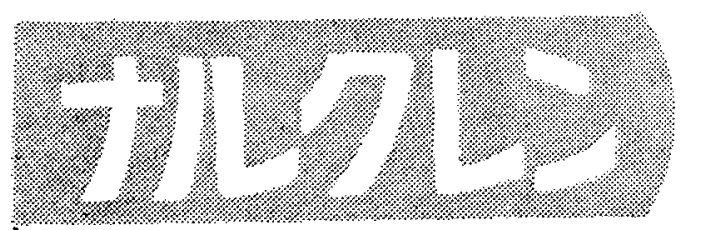

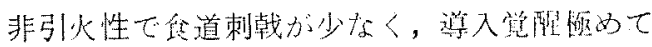

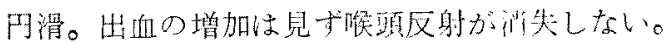

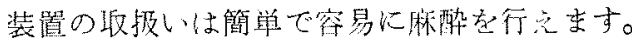

【適応症】鼓膜切開。穿刺，耳節乞の他膿晹切開，中耳根手術．錐体手術。

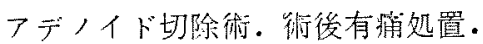

\section{NARCHLENE}

トリフロールIチレン吸入麻醉萗

$$
\text { 殷売元 }
$$

株式会社 建 部 青 州堂 アコマ医科工業株式会社

東京都交京区春木町 2 丁目 東京都文京区本郷: 1 丁目

\section{製 造 元 日本アセチレン化学工業株式会社}

